\title{
ANALISIS SWOT MANAJEMEN ZAKAT PADA LEMBAGA AMIL ZAKAT INFAQ SEDEKAH NAHDLATUL ULAMA (LAZISNU) KABUPATEN MAGETAN
}

\author{
Muhammad Syaiful Imam Baidowi ${ }^{1}$, Said Abadi ${ }^{2}$ \\ ${ }^{1,2}$ Institut Agama Islam Negeri Ponorogo, Indonesia \\ Email: Baidowi69@gmail.com ${ }^{1}$, abadi@iainponorogo.ac.id ${ }^{2}$
}

\begin{abstract}
The purpose of this study is to find out the management of zakat conducted by the district of magetan district by using the swot method of analysis. Which later in swot analysis USES matics and swot analysis diagrams so that it can be known in the upper quadrant of zakat lazisnu's management in the diagram. The study employed qualitative methods of fieldwork and employed qualitative approaches. The data-collection techniques that are done are interviews, observations, and documentation. Research shows that lazisnu has performed some zakat management activities such as planning, organization, execution and surveillance strategies.. Swot analysis using mattices and diagrams indicates that zakat lazisnu's management was in the first quadrant. In the diagram it shows that the first quadrant is between chance and strength. The strategy that supported lazisnu is an aggressive strategy by maximizing the remaining forces to achieve the odds. However, when this strategy is employed incorrectly, it reduces the weaknesses and threats found in lazisnu.
\end{abstract}

Keywords: Management Zakat, SWOT, LAZISNU

Abstrak: Tujuan penelitian ini adalah untuk mengetahui manajemen zakat yang dilakukan oleh LAZISNU Kabupaten Magetan dengan menggunakan metode analisis SWOT. Yang nantinya dalam analisis SWOT menggunakan matrik dan diagram analisis SWOT sehingga dapat diketahui dalam posisi kuadran manakan manajemen zakat LAZISNU dalam diagram. Penelitian ini menggunakan metode kualitatif penelitian lapangan dan menggunakan pendekatan kualitatif. Teknik pengumpulan data yang dilakukan adalah wawancara, observasi, dan dokumentasi. Hasil penelitian menunjukkan bahwa LAZISNU telah melakukan beberapa kegiatan manajemen zakat seperti perencanaan, pengorganisasian, strategi pelaksanaan dan pengawasan.. Hasil analisis SWOT menggunakan matrik dan diagram menunjukkan bahwa manajemen zakat LAZISNU berada di kuadran pertama. Dalam diagram ditunjukkan bahwa kuadran pertama berada di antara peluang dan kekuatan. Strategi yang mendukung LAZISNU adalah strategi agresif yaitu dengan memaksimalkan kekuatan yang ada untuk meraih peluang yang ada. Namun, jika strategi ini dapat dilakukan dengan baik secara tidak langsung akan mengurangi kelemahan dan ancaman yang ada di LAZISNU.

Kata Kunci: Manajemen Zakat, SWOT, LAZISNU

\section{PENDAHULUAN}

Zakat merupakan bagian dari rukun Islam. Zakat adalah ibadah yang penting, strategis, baik dari ajaran Islam maupun dari segi pembangunan kesejahteraan masyarakat. Orang yang menunaikan zakat dianggap telah menempuh jalan untuk 
menyucikan harta dan dirinya. (Nurul, 2015) Pengertian zakat merupakan sesuatu yang menyucikan ini dijelaskan lebih lanjut dalam firman Allah Swt Q.S At-Taubah ayat 103. Berikut ini:

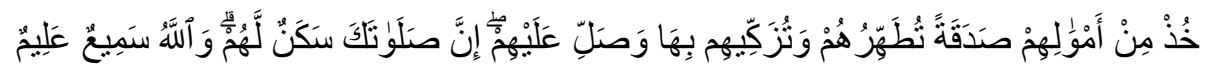

Artinya: "Ambillah zakat dari sebagian harta mereka, dengan zakat itu kamu membersihkan dan mensucikan mereka dan mendoalah untuk mereka. Sesungguhnya doa kamu itu (menjadi) ketenteraman jiwa bagi mereka. Dan Allah Maha Mendengar lagi Maha Mengetahui."(Departemen Agama RI, 2007)

Untuk menjadikan masyarakat yang hidup lebih baik dan berkembang diperlukan adanya manajemen zakat yang dilakukan oleh lembaga atau badan zakat. Pengelolaan zakat yang diharapkan ideal maka diperlukan strategi yang baik untuk mencerminkan lembaga amil zakat yang memiliki kemampuan teknis ilmiah untuk mencapai tujuannya. Pengertian pengelolaan zakat, yaitu pengelolaan zakat merupakan kegiatan perencanaan, pelaksanaan, dan pengoordinasian dalam pengumpulan, pendistribusian, dan pendayagunaan zakat (UU RI No. 23 Tahun 2011 Tentang Pengelolaan Zakat., n.d.). Dalam mencapai tujuannya lembaga amil zakat harus melakukan beberapa kegiatan yaitu, merencanakan program organisasi pengelola zakat (OPZ), pengorganisasian, strategi, melakukan pelaksanaan dan pengawasan dapat mencapai apa yang menjadi tujuan dari lembaga amil tersebut. Dalam undang-undang tersebut juga menjelaskan bahwa lembaga amil zakat harus professional, amanah, terpercaya, dan memiliki program kerja yang jelas baik dari penghimpunan dana sampai pendistribusianya sehingga dapat meningkatkan kualitas hidup mustahiq (Anwar, 2020).

Bicara Tentang zakat, yang terpenting dari zakat tersebut adalah peran amil zakat sebagai pengelola dana zakat. Jika amil zakat mampu melakukan dengan baik, maka asnaf juga akan meningkat kesejahteraannya. Tetapi jika amil zakat tidak mengerjakan pengelolaan zakat dengan baik, maka kesejahteraan delapan asnaf yang lain hanya impian belaka, inilah nilai strategis amil. Dengan kata lain, bagian terpenting dari zakat adalah bagaimana kebiasaan manajemenya sehingga bisa mensejahterakan asnafnya.

Pengelolaan zakat dilakukan oleh badan amil yang dibentuk oleh otoritas pemerintah yang dibentuk dalam suatu badan atau lembaga (Pangiuk, 2020). Pada saat ini terdapat banyak lembaga, yayasan dan organisasi yang mendirikan lembaga amil zakat di lingkup lokal daerahnya masing-masing, semua itu adalah demi memberikan 
layanan terhadap masyarakat muslim. Sebagai contoh telah berdiri Lembaga Amil Zakat, Infaq dan Sedekah Nahdlatul Ulama (LAZISNU) di Kabupaten Magetan. Lembaga Amil Zakat Infaq dan Shadaqah Nahdlatul Ulama (LAZISNU) adalah lembaga pengelola dana zakat, infaq, sedekah yang melakukan pengelolaan secara amanah dan profesional demi kesejahteraan umat. Namun dalam proses pelaksanaannya pasti terdapat beberapa kendala yang dapat menghambat proses pengelolaan zakatnya.

Hasil wawancara yang dilakukan dengan bapak Agus Maftuh ketua LAZISNU Kabupaten Magetan, ada beberapa masalah dalam pelaksanaan manajemen zakat pada LAZISNU Kabupaten Magetan. Pertama, kurangnya sosialisasi yang dilakukan oleh LAZISNU. Di mana sosialisasi kepada masyarakat sangat penting demi membangun kesadaran masyarakat dalam membayar zakat, selain itu sosialisasi tersebut dapat mempengaruhi masyarakat untuk melakukan keputusan berzakat di kalangan umat Islam. Sosialisasi dapat mempengaruhi pemahaman tentang pembayaran zakat serta kesadaran individu umat Islam yang masih kurang, serta memberikan hikmah tentang pentingnya membayar zakat. Maka dari itu, penting bagi LAZISNU Kabupaten Magetan untuk mengedukasi masyarakat betapa pentingnya zakat bagi kesejahteraan, membangun kepercayaan kepada lembaga amil zakat serta memberikan pemahaman kepada masyarakat tetang lembaga amil zakat tersebut, dan hal tersebut dapat di raih oleh LAZISNU jika melakukan sosialisasi kepada masyarakat secara masif (Rafi'i, Tarmizi, \& Badaruddin, 2020).

Kedua, kurangnya sumber daya manusia (SDM) sehingga mengakibatkan pelaksanaan manajemen zakat sedikit terhambat, seperti yang dikatakan oleh bapak Agus Maftuh dalam wawancara, "Untuk di LAZISNU sebenarnya masih kekurangan sumber daya manusia dikarenakan sulit mencari orang yang benar-benar berjuang mau dalam bidang zakat ini."

Dari hasil wawancara tersebut dapat disimpulkan bahwa dalam pelaksanaan manajemen zakat di LAZISNU Kabupaten Magetan masih kekurangan sumber daya manusia baik dari segi kuantitas maupun kualitas, mengingat betapa pentingnya SDM yang produktif dan berkualitas sebagai penunjang roda kehidupan, penggerak, pemikir dan perencana untuk mencapai tujuan organisasi (Safa'ah, 2019). Selain itu, sumber daya manusia yang berkualitas dapat meningkatkan efektivitas dan efisiensi pelayanan dalam pengelolaan zakat. 
Ketiga, LAZISNU belum memiliki kantor sendiri, selama ini LAZISNU masih berada di ruang sekretariat Kantor PCNU Kabupaten Magetan. Perlu diketahui bahwa memiliki kantor sendiri adalah hal yang sangat penting bagi setiap lembaga zakat, khususnya LAZISNU Kabupaten Magetan. Karena segala kegiatan pelaksanaan mudah dilakukan jika sudah ada kantor. Permasalahannya di LAZISNU saat ini yang disebabkan belum adanya kantor sendiri itu seperti, administrasi tidak tertata sehingga proses kegiatan manajemen zakat menjadi sedikit terhambat.

Keempat, dalam pendistribusiannya presentase antara pendistribusian secara produktif dan konsumtif masih banyak ke pendistribusian ke konsumtif seperti beras, minyak, gula, beasiswa dan lain-lain. Dikarenakan melihat situasi yang sekarang masyarakat yang membutuhkan barang yang bersifat konsumtif. Selain itu untuk mendistribusikan ke produktif membutuhkan dana yang tidak sedikit sedangkan untuk penghimpunannya saja masih belum maksimal sehingga untuk melakukan pendistribusian secara produktif masih sedikit. Dari hal tersebut dapat disimpulkan bahwasanya pendistribusian di LAZISNU belum mencapai tujuan pengelolaan zakat yaitu meningkatkan manfaat zakat untuk mewujudkan kesejahteraan masyarakat dan penanggulangan kemiskinan.

Beberapa masalah yang dihadapi oleh lembaga-lembaga pengumpul zakat. Antara lain seperti problem sosialisasi sehingga mengakibatkan kurangnya pengumpulan dana zakat misalnya dalam LAZISNU pengumpulan zakat pada tahun lalu baru sekitar 300.000.000 walaupun grafik pengumpulanya naik dai tahun sebelumnya, masalah sumber daya manusia (SDM) seperti di LAZISNU baru ada sembilan anggota dan itupun masih ada kesibukan lain di samping menjadi anggota LAZISNU, Masalah penyaluran dana zakat yang persentasenya banyak ke konsumtif disebabkan salah satunya adalah masih kurang maksimal dalam hal pengumpulan dana zakat.

Dapat disimpulkan bahwa pada LAZISNU terdapat beberapa problem sehingga membuat pengumpulan dana tidak maksimal. Sebab lembaga nirlaba seperti LAZISNU ini modal utamanya adalah kepercayaan masyarakat. Kepercayaan tersebut diperoleh dengan sosialisasi secara masif agar dapat memkasimalkan pengumpulan zakatnya sehingga grafik pengumpulannya bisa naik secara signifikan, adanya manajemen yang baik transparansi distribusi dana, dan berbagai strategi jemput dana baik secara langsung maupun melalui aplikasi. Dari hal tersebut untuk menganalisis manajemen zakat pada LAZISNU Kabupaten Magetan dengan analisis strategi SWOT. Organisasi 
atau perusahaan membutuhkan analisis, yaitu adalah analisis Strength, Weakness, Opportunity, Threat (SWOT) tujuan utama perencanaan strategi adalah agar perusahaan dapat melihat secara objektif kondisi-kondisi internal dan eksternal, sehingga perusahaan dapat mengantisipasi perubahan lingkungan eksternal.

\section{TINJAUAN LITERATUR}

\section{Analisis SWOT}

Analisis SWOT berasal dari kata Strengths (Kekuatan) dan Weakness (Kelemahan) dari internal perusahaan serta Opportunities (peluang) dan Threats (ancaman) dari lingkungan eksternal. Analisis SWOT adalah teknik historis di mana manajer dapat menciptakan gambaran umum mengenai situasi strategi perusahaan. Tujuan akhir analisis SWOT adalah memberikan berbagai alternatif strategi. Sehingga strategi tersebut mudah diterapkan dan diaplikasikan pada perusahaan(Wardoyo, 2011). Analisis ini berdasarkan asumsi bahwa strategi efektif adalah kesesuaian dari sumber daya internal dengan eksternal. Kesesuaian ini akan dapat memanfaatkan kekuatan dan peluang serta meminimalkan kelemahan dan ancaman(Sedarmayanti, 2014).

a. Kekuatan (Strengths)

Kekuatan adalah segala hal yang tersedia bagi perusahaan yang membuat organisasi lebih unggul dibanding dengan pesaingnya dalam melayani kebutuhan pelanggan. Kekuatan muncul dari kompetensi yang tersedia dari sumber daya milik organisasi.

b. Kelemahan (Weakness)

Kelemahan merupakan keterbatasan yang dimiliki organisasi dalam beberapa sumber daya suatu organisasi, sehingga akan menjadi kurang efektif dalam memenuhi kebutuhan para pelanggan.

c. Peluang (Opportunities)

Peluang adalah situasi yang sangat menguntungkan dalam lingkungan eksternal suatu organisasi. Kecenderungan organisasi merupakan bagian dari sumber peluang.

d. Ancaman (Threats)

Ancaman adalah situasi yang tidak menguntungkan dalam lingkungan organisasi. Ancaman akan menjadi penghalang utama bagi organisasi dalam mencapai tujuan yang diinginkan(Sedarmayanti, 2014). 
Analisis SWOT merupakan pengolahan berbagai faktor secara sistematis untuk menetapkan perumusan strategi organisasi. Analisis ini didasarkan ketika memaksimalkan kekuatan dan peluang di perusahaan, secara tidak langsung akan meminimalkan kelemahan dan ancaman. Perencanaan strategis berkaitan dengan penetapan pengembangan misi, tujuan, strategi dan kebijakan. Perencanaan strategis harus menganalisis faktor strategis perusahaan dalam kondisi saat ini(Rangkuti, 1998).

\section{Diagram Analisis SWOT}

Penelitian menunjukkan bahwa kinerja suatu organisasi dapat ditentukan dengan faktor internal dan eksternal yang dikombinasikan. Dalam analisis SWOT kedua faktor itu harus dipertimbangkan. SWOT singkatan dari strength dan weaknesses dari lingkungan internal, serta opportunity dan threats dari lingkungan eksternal. Analisis SWOT membandingkan antara faktor internal dan faktor eksternal(Rangkuti, 1998).

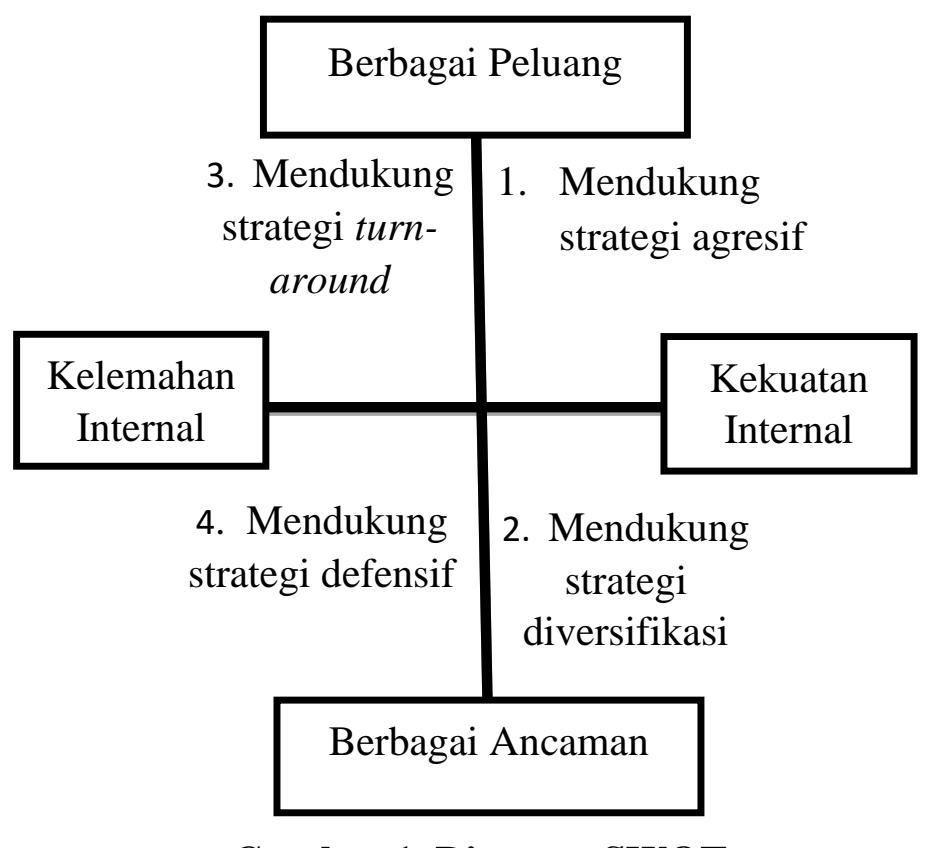

Gambar 1. Diagram SWOT

Kuadran 1: Situasi sangat menguntungkan bagi organisasi tersebut karena mempunyai peluang dan kekuatan. Sehingga dengan kekuatan tersebut dapat memanfaatkan peluang yang ada. Strategi yang diterapkan pada kuadran ini adalah strategi yang mendukung kebijakan pertumbuhan secara agresif. 
Kuadran 2: Menghadapi banyak ancaman, tetapi organisasi masih mempunyai kekuatan dari internal. Strategi yang diterapkan memakai kekuatan yang ada untuk memaksimalkan peluang jangka panjang dengan diversifikasi.

Kuadran 3: Organisasi mempunyai peluang yang besar, tetapi memiliki kelemahan internal. Strategi yang diterapkan adalah mengurangi kelemahan internal sehingga dapat meraih peluang pasar dengan baik.

Kuadran 4: merupakan situasi yang tidak menguntungkan, karena organisasi menghadapi ancaman dan kelemahan internal(Rangkuti, 1998).

\section{Matrik Faktor Strategi Internal dan Eksternal}

Sebelum membuat matrik faktor internal dan eksternal, kita perlu mengetahui faktor strategi internal (IFAS) dan faktor strategi eksternal (EFAS). Berikut adalah cara penentuan IFAS dan EFAS:

a. Menyusun dalam kolom 1(5 sampai 10 Faktor internal dan eksternal)

b. Memberi bobot pada faktor tersebut dalam kolom 2, mulai dari 1,0 (sangat penting) sampai 0,0 (tidak penting)

c. Menghitung rating pada kolom 3 untuk masing-masing faktor dengan skala mulai dari 4 (outstanding) sampai 1 (poor).

d. Mengalikan bobot pada kolom 2 dengan rating pada kolom 3 1, untuk mendapatkan faktor pembobotan di kolom 4. Hasilnya berupa skor pembobotan pada faktor yang nilainya bervariasi.

e. Menjumlah skor pembobotan pada kolom 4, untuk memperoleh total skor bagi organisasi yang bersangkutan(Rangkuti, 1998).

\section{Kuisioner SWOT}

Dalam menangkap aspirasi agar organisasi menjadi lebih baik sesuai dengan visi dan misi organisasi, diperlukan riset SWOT. Tujuan dari hasil pengolahan kuisioner ini adalah:

a. Menganalisis dan mengklasifikasikan faktor internal dan eksternal yang mempengaruhi suatu organisasi

b. Menganalisis faktor pendorong, memetakan, dan mendefinisikan strategi berdasarkan pemetaan. 
c. Melihat berbagai alternatif kebijakan yang dilakukan berdasarkan peluang dan ancaman ke depan.

d. Hasil dari kuisioner adalah angka(Rangkuti, 1998).

Kuesioner tersebut memiliki dua penilaian yaitu penilaian kondisi saat ini dan penilaian urgensi. Penilaian kondisi saat ini merupakan responden diminta menilai kinerja organisasi saat ini. Sedangkan Penilaian urgensi adalah penilaian yang berhubungan dengan skala prioritas dimana responden diminta menilai urgensi faktor tersebut untuk ditangani.

\section{Manajemen Zakat}

Pengertian pengelolaan zakat yaitu, pengelolaan zakat adalah kegiatan perencanaan, pelaksanaan, dan pengoordinasian dalam pengumpulan, pendistribusian, dan pendayagunaan zakat. UU Pengelolaan Zakat sebelumnya yaitu UU No 38 tahun 1999, mendefinisikan pengelolaan zakat sebagai kegiatan perencanaan, pelaksanaan dan pengawasan terhadap pengumpulan dan pendistribusian serta pendayagunaan zakat.

Menggabungkan antara dua pengertian pengelolaan zakat dari kedua undangundang pengelolaan zakat tersebut, maka pengelolaan zakat adalah kegiatan perencanaan, pelaksanaan, pengkoordinasian, dan pengawasan terhadap pengumpulan, pendistribusian, dan pendayagunaan. Terdapat dua unsur penting dalam proses manajemen zakat yaitu, pengumpulan dan pendistribusian zakat.

Dari penjelasan diatas, bisa diambil kesimpulan bahwa tujuan pengelolaan zakat untuk:

a. Meningkatkan pelayanan untuk masyarakat agar dapat menjalankan kewajiban zakat yang sesuai dengan syariat Islam.

b. Meningkatkan peran dan fungsi instrumen keagamaan dalam mewujudkan kesejahteraan dan keadilan sosial.

c. Mengoptimalkan daya guna zakat(Nurhayati et al., 2019).

Untuk mencapai tujuan yang dirumuskan pengelolaan zakat harus dilaksanakan secara modern dan profesional. Dari segi penyaluran dana, maka pendistribusian zakat tidak hanya diberikan berupa barang konsumtif saja, akan tetapi dikelola secara produktif agar yang selama ini menjadi mustahiq bisa berubah menjadi muzakki. Artinya, bentuk pendistribusian dikelola secara produktif sehingga menjadikan 
mustahiq dapat meningkatkan ekonominya, tidak hanya bergantung kepada lembaga zakat yang pada akhirnya membuat mereka malas.

\section{Perencanaan Program Organisasi Pengelola Zakat (OPZ)}

Perencanaan adalah salah satu proses pengelolaan dalam sebuah organisasi. Bagi masyarakat awam, perencanaan seperti sesuatu yang sederhana, yakni menentukan apa yang ingin dilakukan. Padahal perencanaan mempertimbangkan apa yang seharusnya dilakukan. Kata seharusnya ini merujuk kepada visi dan misi atau rencana strategis organisasi. Sehingga, rencana strategis harus menjadi acuan utama ketika organisasi menentukan perencanaan kedepan(Nurhayati et al., 2019). Dalam proses perencanaan, terdapat kegiatan yang harus dilaksanakan, yaitu:

a. Menetapkan tujuan dan target organisasi.

b. Merumuskan strategi untuk mencapai tujuan dan target.

c. Menentukan sumber daya yang diperlukan.

d. Menetapkan standar keberhasilan dalam mencapai tujuan dan target(Nurhayati et al., 2019).

Di sisi lain perencanaan strategis lembaga zakat adalah perencanaan yang dilakukan demi menjaga fleksibilitas rencana jangka panjang akibat berubahnya situasi. Perencanaan ini guna menjaga stabilitas dan eksistensi lembaga zakat terhadap berubahnya waktu dan kondisi. Beberapa faktor kunci perencanaan strategis yaitu, faktor kepercayaan, perubahan terhadap masyarakat, kelangsungan dan pemeliharaan dari lembaga zakat.

\section{Pengorganisasian $\mathrm{OPZ}$}

Pengorganisasian adalah salah satu bagian dari proses manajemen. Dalam tahap ini organisasi membuat struktur organisasi berdasarkan dengan analisis visi misi, lingkungan organisasi, dan kegiatan yang akan dilakukan. Penataan ruang kegiatan organisasi, penetapan wewenang dan tugas juga masuk dalam tahap ini. Koordinasi antara anggota organisasi merupakan hal yang sangat penting dalam proses pengorganisasian. Faktor penting koordinasi dalam lembaga pengelola zakat adalah
a. Pimpinan lembaga zakat
b. Kualitas anggota
c. Sistem lembaga zakat
d. Kesadaran bersama 
Lembaga zakat dapat eksis dan terus bertahan berasal dari memiliki sistem yang baik dalam pengelolaan zakat antara lain, struktur organisasi, job description, mekanisme birokrasi, sistem komunikasi, dan transparansi anggaran

\section{Strategi OPZ}

Untuk meningkatkan kualitas pengorganisasian guna mencapai kinerja OPZ yang semakin baik terdapat strategi yang dapat dijalankan, yaitu:

a. Pemanfaatan teknologi informasi

b. Struktur organisasi yang sesuai dengan kondisi yang ada di OPZ

c. Pengambilan keputusan yang cepat dan berorientasi pada visi, misi dan tujuan organisasi.

\section{Pelaksanaan dan Pengawasan}

Dalam lembaga zakat pelaksanaan adalah bentuk aksi dari perencanaan yang dibuat oleh lembaga zakat. Agar pelaksanaan kegiatan lembaga berjalan sesuai dengan rencana haruslah diberi pengarahan terhadap setiap anggota lembaga. Faktor penting dalam pelaksanaan adalah, motivasi, komunikasi, dan gaya kepemimpinan.

Pengawasan merupakan suatu proses untuk menetapkan indikator keja organisasi dan pengambilan keputusan yang mendukung proses kinerja organisasi sehingga dapat mencapai hasil yang diharapkan. Sebagai bentuk upaya dalam mencapai sasaran kinerja organisasi, organisasi pengelola zakat harus membuat sebuah dewan yang melakukan proses pengawasan, pemeriksaan, dan evaluasi melalui penilaian terhadap pelaksanaan sistem organisasi secara keseluruhan.

Pengawasan dalam lembaga zakat bisa berbentuk neraca keuangan dan kegiatan lembaga zakat yang terbuka untuk dilakukan audit. Segala kegiatan harus dilaporkan kepada masyarakat sebagai bentuk pertanggungjawaban dan transparansi pengelolaan dana zakat. Disisi lain sistem akuntansi dan manajemen keuangan lembaga zakat harus diperhatikan. Dengan sistem akuntansi dan manajemen yang baik itu penting sebagai sarana untuk mencapai beberapa tujuan. Sistem akuntansi dan manajemen yang baik antara lain, dana dikelola sesuai dengan syariat Islam, pertanggungjawaban terhadap masyarakat dan muzakki dapat dilaksanakan, dana dikelola secara tepat, efektif dan efisien, kebutuhan terantisipasi secara tepat, dan keamanan dana terjamin. 
Dalam penelitian ini, peneliti dalam teori manajemen zakat lebih cenderung menggunakan teori dari Sri Nurhayati dan kawan-kawan. Karena dalam teori milik Sri Nurhayati tersebut lebih komplek dan lebih mudah untuk dipahami

\section{METODE PENELITIAN}

Penelitian ini menggunakan data primer dan sekunder. Data primer adalah data yang langsung memberikan data kepada pengumpul data.(Sugiyono, 2006) Peneliti memperoleh data langsung dengan cara menggali informasi dari informan atau responden dan catatan lapangan yang relevan dengan masalah yang diteliti. Data primer diperoleh dari hasil wawancara dengan Kepala Lembaga Amil Zakat Infaq Sedekah Nahdlatul Ulama (LAZISNU) Kabupaten Magetan. Sedangkan data sekunder adalah sumber yang tidak langsung memberikan kepada pengumpul data(Sugiyono, 2006). Data sekunder yang mendukung penelitian ini adalah informan lain seperti masyarakat sekitar, buku-buku pendukung, hasil penelitian yang terdahulu, jurnal, artikel dan anggota LAZISNU yang memberikan pendapat yang berkaitan langsung dengan permasalahan yang diangkat serta dapat membantu mengembangkan penelitian ini..

Data tersebut selanjutnya digunakan dalam menentukan kekuatan, kelemahan, peluang, dan posisi organisasi pengelola zakat (OPZ) dalam diagram analisis SWOT. Posisi tersebut digunakan sebagai dasar penentuan dasar strategi manajemen zakat yang sebaiknya di terapkan oleh LAZISNU Kabupaten Magetan.

Analisis SWOT dapat menunjukkan kinerja perusahaan dengan kombinasi antara faktor internal dan faktor eksternal. Kedua factor tersebut harus menjadi pertimbangan dalam membuat analisis SWOT. SWOT sendiri adalah singkatan dari strengths dan Weaknesses dari lingkungan internal perusahaan dengan opportunities dan Threats dari lingkungan eksternal perusahaan(Rangkuti, 1998). Untuk mengetahui bagaimana kinerja perusahaan dengan metode analisis SWOT adalah menggunakan matrik dan diagram analisis SWOT. Dalam diagram analisis SWOT dibagi dalam 4 strategi yaitu:

Kuadran 1: strategi SO yaitu memanfaatkan seluruh kekuatan untuk merebut dan memanfaatkan peluang sebaesarnya. Strategi yang harus diterapkan pada kuadran ini adalah strategi agresif yang mendukung kebijakan pertumbuhan. 
Kuadran 2: strategi ST yaitu menggunakan kekuatan yang dimiliki guna mengatasi ancaman. Strategi yang diterapkan berupa strategi diversifikasi yaitu membuat produk yang serupa akan tetapi memiliki perbedaan dari segi lain.

Kuadran 3: strategi WO yaitu oemanfaatan peluang yang ada guna meminimalkan kelemahan. Strategi yang diterapkan pada kuadran ini adalah strategi defensif yaitu dengan meminimalkan kelemahan yang ada agar dapat merebut peluang yang besar tersebut. Kondisi pada kuadran ini sama seperti produk Apple yang meninjau kembali teknologi yang dipergunakan dengan cara menawarkan produkproduk baru dalam industri.(Rangkuti, 1998)

Kuadran 4: strategi WT ysitu kegiatan defensive dan berusaha meminimalkan kelemahan dan menghindari ancaman. Akan tetapi organisasi yang berada dalam posisi ini risikonya sangat besar karenan menghadapi berbagai ancaman dan kelemahan internal(Rangkuti, 1998).

\section{HASIL DAN PEMBAHASAN}

Setiap organisasi atau lembaga pasti mempunyai visi dan misi sendiri yang menjadi tujuan dari dibentuknya organisasi dan lembaga tersebut. Tentunya untuk mencapai tujuan organisasi diperlukan yang namanya faktor yang mendukung organisasi baik dari dalam organisasi maupun dari luar organisasi. Dari hasil wawancara dan observasi di LAZISNU saya menemukan beberapa indikator baik dari dalam LAZISNU maupun luar LAZISNU untuk mencapai visi dan misi yang dimiliki. Faktor tersebut terbagi menjadi dua yaitu, faktor strategi internal (IFAS) dan faktor strategi eksternal (EFAS). Faktor strategi internal dari LAZISNU adalah:

\section{Tabel 1 Faktor Strategi Internal}

\begin{tabular}{ll}
\hline \multicolumn{2}{l}{ Kekuatan } \\
\hline 1. & Independen \\
\hline 2. & Tepat Sasaran \\
\hline 3. & Memiliki dukungan UPZIS \\
\hline 4. & Selalu update perkembangan zakat \\
\hline 5. & Pelayanan \\
\hline 6. & Memiliki jaringan yang luas \\
\hline Kelemahan \\
\hline 7. & Sumber daya manusia \\
\hline 8. & Belum adanya kantor \\
\hline 9. & Sosialisasi \\
\hline 10. & Tanggung jawab \\
\hline Sumber dari hasil olah data wawancara dan observas
\end{tabular}


Tabel 2 Faktor Strategi Eksternal

\begin{tabular}{ll}
\hline \multicolumn{2}{l}{ Peluang } \\
\hline 1. & Mayoritas muslim \\
\hline 2. & Alam yang mendukung \\
\hline 3. & Dukungan ulama \\
\hline 4. & Kerjasama dengan pihak lain \\
\hline 5. & Potensi zakat \\
\hline 6. & Perkembangan teknologi \\
\hline Ancaman \\
\hline 7. & Persaingan LAZ \\
\hline 8. & Kepercayaan masyarakat \\
\hline 9. & Terjadinya resesi \\
\hline 10. & Dukungan pemerintah \\
\hline
\end{tabular}

Sumber dari hasil olah data wawancara dan observasi.

\section{Kekuatan LAZISNU}

Kekuatan adalah nilai plus dari sebuah organisasi. faktor-faktor kekuatan merupakan suatu keunggulan yang terapat dalam organisasi tersebut. Berdasarkan data pada Tabel 1, LAZISNU memiliki kekuatan yang menjadi keunggulan seperti:

1. Independen

Maksud independen LAZISNU disini adalah LAZISNU tidak terkait sama sekali dengan politik apapun. Walaupun sampai sekarang banyak yang meminta LAZISNU untuk memberikan bantuan dana dari suatu politik tetapi dari pihak LAZISNU selalu menolak. Dengan alasan tidak mau ikut campur dengan urusan politik, sebab lembaga seperti LAZISNU ini menurut para politikus merupakan salah satu strategi yang baik untuk menarik minat masyarakat.

2. Tepat sasaran

Setiap pengelolaan yang dilakukan oleh lembaga zakat khususnya LAZISNU pasti nantinya akan di distribusikan ke asnaf. Selama ini LAZISNU telah mendistribusikan secara tepat ke asnaf tersebut. Karena sebelum memberikan bantuan LAZISNU selalu melihat apakah orang tersebut layak dibantu atau tidak. Selain itu LAZISNu juga membedakan antara pendistribusian dana zakat dengan dana infaq dan sedekah sehingga proses pendistribusian dananya tidak tercampur.

3. Memiliki dukungan UPZIS

Hampir setiap kecamatan di Magetan sudah memiliki UPZIS dari LAZISNU sampai sekarang hanya tinggal dua kecamatan yang belum ada. Adanya UPZIS disini sangat membantu proses manajemen zakat yang dilakukan oleh LAZISNU. Karena 
kota Magetan itu mempunyai wilayah yang sangat luas dan tidak mungkin hanya satu LAZISNU bisa mencapai semua wilayah di Magetan. Dari situlah pentingnya adanya dukungan dari UPZIS disetiap kecamatan gunanya untuk mencapai daerah yang sulit dicapai oleh LAZISNU Kabupaten Magetan.

4. Selalu update perkembangan zakat

Update yang dilakukan oleh LAZISNU ini dilihat dari perkembangan secara umum maupun secara fiqh. Biasanya LAZISNU dapat update perkembangan zakat ini dilihat dari website $\mathrm{Nu}$ Online maupun website yang membahas tentang zakat infaq dan sedekah. Selain dari website Update perkembangan zakat yang dilakukan oleh LAZISNU juga melalui perkemangan fiqh.

5. Pelayanan

Pelayanan di LAZISNU sudah bagus, misalnya ketika dalam pengumpulan dana LAZISNU memberikan tawaran sesuai dengan keinginan donator apakah melalui jemput dana atau via rekening bank. Tentu itu akan membuat suatu hubungan yang baik dengan donatur. Selain itu untuk pendistribusian LAZISNU langsung mengerahkan UPZIS disetiap kecamatan untuk memberikan bantuan kepada yang membutuhkan. Selain itu ada beberapa UPZIS yang sudah mempunyai ambulance sendiri yang gunanya untuk membantu masyarakat.

6. Memiliki jaringan yang luas

Jaringan yang dimaksud disini adalah langkah yang dibuat oleh LAZISNU Kabupaten Magetan. Untuk membuatkan SK untuk setiap panitia zakat yang di masjid dan merubahnya dari panitia zakat menjadi amil zakat.

\section{Kelemahan LAZISNU}

Kelemahan merupakan sebuah kekurang yang ada dalam organisasi khususnya organisasi pengelola zakat. Setiap suatu organisasi pastinya memiliki kelemahan sendiri khususnya pada LAZISNU Kabupaten Magetan. Kelemahan tersebut adalah:

1. Sumber daya manusia

SDM memiliki peranan yang sangat penting bangi setiap organisasi. Karena SDM adalah pelaku dari proses manajemen. Dalam LAZISNU sudah terdapat beberapa anggota yang sudah ditugaskan sesuai dengan kemampuan masing-masing. Namun menurut observasi dan wawancara, menunjukkan bahwa LAZISNU masih 
kekurangan SDM baik dari segi kualitas maupun kuantitas. Karena sulit untuk menemukan orang yang benar-benar mau berjuang didalam LAZISNU.

2. Belum adanya kantor

Belum memiliki kantor sendiri merupakan persoalan yang sangat besar. Salah satunya persoalannya adalah ketika belum mempunyai kantor sendiri mengakibatkan kesulitan untuk menempatkan dokumen administrasi dari LAZISNU. Selama ini dokumen tersebut masih berada di beberapa tempat dan belum menjadi satu tempat sehingga kadang apabila ada keperluan dengan suatu dokumen pasti harus mencari terlebih dahulu. Selain itu, proses pelaksanaan kegiatan di LAZISNU jadi kurang maksimal.

3. Sosialisasi

Sosialisasi sangat penting bagi setiap lembaga zakat. Karena dengan sosialisasi dapat memperkenalkan lembaga zakat tersebut. Selain itu dengan sosialisasi secara masif dapat menambah donatur yang ingin mengeluarkan zakatnya ke LAZISNU. Sosialisasi juga dapat menambah kepercayaan masyarakat terhadap LAZISNU. Dalam wawancara dan observasi menunjukkan bahwa LAZISNU masih kurang dalam hal sosialisasi terutama sosialisasi dalam media massa. Sebab media massa yang digunakan oleh LAZISNU selama ini hanya facebook, whatapps dan website $N U$ online. Padahal masih banyak platform media massa yang dapat mendukung sosialisasi di LAZISNU seperti youtube, instagram, tik tok dan sebagainya.

4. Tanggung jawab

Hal yang harus ditekankan terhadap setiap anggota LAZISNU adalah tanggung jawabnya. Sebab jika para anggota lalai terhadap tanggung jawabnya akan memiliki risiko yang sangat tinggi. Kemungkinan terbesarnya masyarakat akan kehilangan kepercayaan jika para anggota lembaga zakat lalai dalam tanggung jawab. Anggota LAZISNU masih lemah terhadap tanggung jawab. Karena banyak anggota LAZISNU yang merangkap dalam pekerjaan lainnya. Sehingga fokus dari anggota LAZISNU masih sedikit kurang

Selain faktor strategi internal (IFAS) dari LAZISNU, ada juga faktor strategi eksternal (EFAS) LAZISNU yang mempengaruhi proses manajemen dari luar LAZISNU. Faktor tersebut adalah: 


\section{Peluang LAZISNU}

Kondisi eksternal yang menguntungkan yang bisa menjadi faktor untuk memanjukan organisasi disebut peluang. Dari hasil wawancara yang telah dilakukan peluang yang dimiliki LAZISNU adalah:

1. Mayoritas muslim

Kabupaten Magetan memiliki masyarakat muslim yang mayoritas. Tentunya ini akan menjadi peluang yang sangat besar bagi LAZISNU. Karena setiap muslim pasti mempunyai kewajiban salah satunya adalah kewajiban untuk mengeluarkan zakatnya baik zakat fitrah maupun zakat maal.

2. Alam yang mendukung

Daerah Magetan merupakan daerah yang memiliki banyak lahan pertanian. Hampir setiap warga di Magetan memiliki profesi sebagai petani. Ini akan menjadi peluang di mana petani juga harus membayar zakat ketika sudah panen. Selain itu, di daerah Magetan juga terdapat banyak pengusaha yang sukses karena banyaknya tempat pariwisata. Pengusaha tersebut tentunya diharuskan membayar zakat apabila pendapatannya sudah mencapai nishob dan haul.

3. Dukungan ulama

Selama ini LAZISNU sangat didukung oleh ulama di mana setiap ada kegiatan yang melibatkan ulama pasti disarankan untuk mengeluarkan zakat, infaq, dan sedekah ke LAZISNU. Selain itu, dengan adanya dukungan dari ulama tentunya dapat membuka peluang bagi LAZISNU dalam mencari muzakki.

4. Kerjasama dengan pihak lain

Kerjasama di tingkat LAZISNU sangat baik, ini terbukti ketika ada program khitanan massal dan operasi katarak. Pihak LAZISNU langsung berkerjasama dengan salah satu dokter ahli dari Kabupaten Malang. Ini tentunya akan membuka peluang bagi ILAZISNU dalam mencari muzakki melalui kerja sama tersebut.

5. Potensi zakat

Kabupaten Magetan memiliki daerah yang sangat luas dan diisi oleh mayoritas muslim. Selain itu, Magetan juga memiliki daerah yang strategis untuk usaha baik di bidang pertanian maupun pariwisata. Ini tentunya merupakan potensi zakat yang sangat besar bagi LAZISNU. 
6. Perkembangan teknologi

Teknologi yang terus berkembang merupakan sebuah potensi yang sangat besar bagi LAZISNU. Di mana dengan teknologi tersebut LAZISNU bisa mensosialisasikan secara masif untuk menarik donatur melalui platform yang ada di media teknologi. Selain itu teknologi yang berkembang akan memudahkan LAZISNU dalam menjalankan proses manajemennya. Salah satu contohnya adalah memudahkan dalam menghitung zakat yang harus dikeluarkan muzakki.

\section{Ancaman di LAZISNU}

Ancaman adalah suatu faktor yang mengganggu berjalanya sebuah organisasi. Ancaman ini sifatnya tidak menguntungkan bagi sebuah oerganisasi. Dari hasil data diatas ancaman yang dimiliki LAZISNU meliputi:

\section{Persaingan LAZ}

Daerah Magetan banyak terdapat lembaga amil zakat selain LAZISNU. Ini tentunya akan menimbulkan persaingan di antara lembaga zakat tersebut. Ini tentunya dapat mempengaruhi masyarakat di mana masyarakat nantinya akan memilih lembaga zakat mana yang memiliki progam dan manajemen zakatnya yang lebih baik. Namun persaingan di antara lembaga zakat di Magetan tergolong ke dalam persaingan yang baik.

2. Kepercayaan masyarakat

Kepercayaan masyarakat selama ini masih belum maksimal dikarenakan sosialisasi yang dilakukan LAZISNU masih kurang. Sehingga masyarakat masih banyak yang langsung memberikan dana zakatnya langsung ke mustahiq. Selain itu, masyarakat juga ada yang memberikan dana zakatnya ke lembaga yang lain.

3. Terjadinya resesi

Pada situasi pandemi seperti ini kemungkinan untuk resesi sangat besar. Dari hasil wawancara bahwa adanya resesi berpengaruh terhadap lembaga amil zakat. Dikarenakan ekonomi masyarakat semakin melemah sehingga tidak dapat memaksimalkan penghimpunan dana.

4. Dukungan pemerintah

Pemerintah untuk sekarang ini hanya membuat regulasi terkait administrasi di lembaga zakat. Padahal yang dilakukan oleh lembaga zakat tidak hanya sekedar 
regulasi. Tetapi juga pengawasan terhadap muzakki yang sudah wajib untuk mengeluarkan zakat tetapi belum mengeluarkan zakatnya.

Dalam penelitian ini menggunakan matrik analisis SWOT, matrik ini menjadi pilihan bagi mayoritas petinggi manajemen, karena didalam matrik ini mengandung unsur kuantitatif yang mudah untuk dipahami, sederhana dan dapat mengurangi unsur subjektif. Dalam mempertegas unsur kuntitatif, matriks ini disusun dengan menentukan bobot dan rating setiap masing-masing faktor baik dari IFAS maupun EFAS. Dari data IFAS dan EFAS kemudian diolah menggunakan matrik SWOT dengan memberikan rating dan bobotnya. Untuk faktor strategi internal (IFAS) ditunjukkan pada Tabel 3 dan Tabel 4 sedangkan faktor strategi eksternal (EFAS) ditunjukkan pada Tabel 5 dan Tabel 6.

Tabel 3 Nilai Rating Faktor Kekuatan

\begin{tabular}{clccc}
\hline NO. & Faktor Kekuatan & Bobot & Rating & Bobot X Rating \\
\hline 1. & Independen & 0,17 & 3.6 & 0.61 \\
\hline 2. & Tepat sasaran & 0.18 & 4 & 0.72 \\
\hline 3. & Dukungan UPZIS & 0.16 & 4 & 0.6 \\
\hline 4. & Update perkembangan zakat & 0.18 & 4 & 0.72 \\
\hline 5. & Pelayanan & 0.17 & 4 & 0.68 \\
\hline 6. & Jaringan yang luas & 0.15 & 4 & 0.6 \\
\hline \multicolumn{4}{c}{ Jumlah } & 1.00 \\
\hline
\end{tabular}

Sumber hasil olah data IFAS dan EFAS.

Tabel 4 Nilai Rating Faktor Kelemahan

\begin{tabular}{|c|c|c|c|c|}
\hline NO. & Faktor Kelemahan & Bobot & Rating & Bobot X Rating \\
\hline 1. & Kurangnya SDM & 0.2 & 3.3 & 0.66 \\
\hline 2. & Belum ada kantor & 0.29 & 4 & 1.16 \\
\hline 3. & Sosialisasi & 0.24 & 4 & 0.96 \\
\hline \multirow[t]{2}{*}{4.} & Tanggung jawab & 0.27 & 4 & 1.08 \\
\hline & Jumlah & 1.00 & & 3.86 \\
\hline
\end{tabular}

Sumber hasil olah data IFAS dan EFAS.

Tabel 5 Nilai Rating Faktor Peluang

\begin{tabular}{|c|c|c|c|c|}
\hline NO. & Faktor Peluang & Bobot & Rating & Bobot X Rating \\
\hline 1. & Mayoritas muslim & 0.17 & 3.3 & 0.56 \\
\hline 2. & Alam yang mendukung & 0.17 & 3.3 & 0.56 \\
\hline 3. & Dukungan ulama & 0.17 & 4 & 0.68 \\
\hline 4. & Kerjasama pihak lain & 0.16 & 4 & 0.64 \\
\hline 5. & Potensi zakat & 0.17 & 3.3 & 0.56 \\
\hline \multirow[t]{2}{*}{6.} & Perkembangan teknologi & 0.15 & 3.3 & 0.5 \\
\hline & Jumlah & 1.00 & & 3.49 \\
\hline
\end{tabular}

Sumber hasil olah data IFAS dan EFAS. 
Tabel 6 Nilai Rating Faktor Ancaman

\begin{tabular}{clccc}
\hline NO. & Faktor Ancaman & Bobot & Rating & Bobot X Rating \\
\hline 1. & Persaingan LAZ & 0.36 & 3 & 1.08 \\
\hline 2. & Kepercayaan masyarakat & 0.33 & 3 & 0.99 \\
\hline 3. & Terjadinya resesi & 0.23 & 2 & 0.46 \\
\hline 4. & Dukungan pemerintah & 0.08 & 2.3 & 0.18 \\
\hline & Jumlah & 1.00 & & 2.71 \\
\hline
\end{tabular}

Sumber hasil olah data IFAS dan EFAS.

Dari Tabel 3 dan Tabel 4 dapat dicari dalam posisi manakah keadaan internal LAZISNU dengan cara dikurangi total bobot $\mathrm{x}$ rating, yaitu: 3.93-3.86 $=0.07$. Sedangkan untuk posisi dari faktor eksternal (EFAS) di LAZISNU dari Tabel 5 dan Tabel 6 adalah 3.49-2.71=0.78. Dari data tersebut dapat diketahui bahwa posisi analisis SWOT faktor eksternal LAZISNU adalah 0.78.

Langkah selanjutnya adalah membuat diagram analisis SWOT menggunakan hasil dari matriks dari Tabel 3 hingga Tabel 6. Kegunaan diagram analisis SWOT ini adalah untuk mengetahui posisi kuadran manakah manajemen zakat di LAZISNU.

Peluang

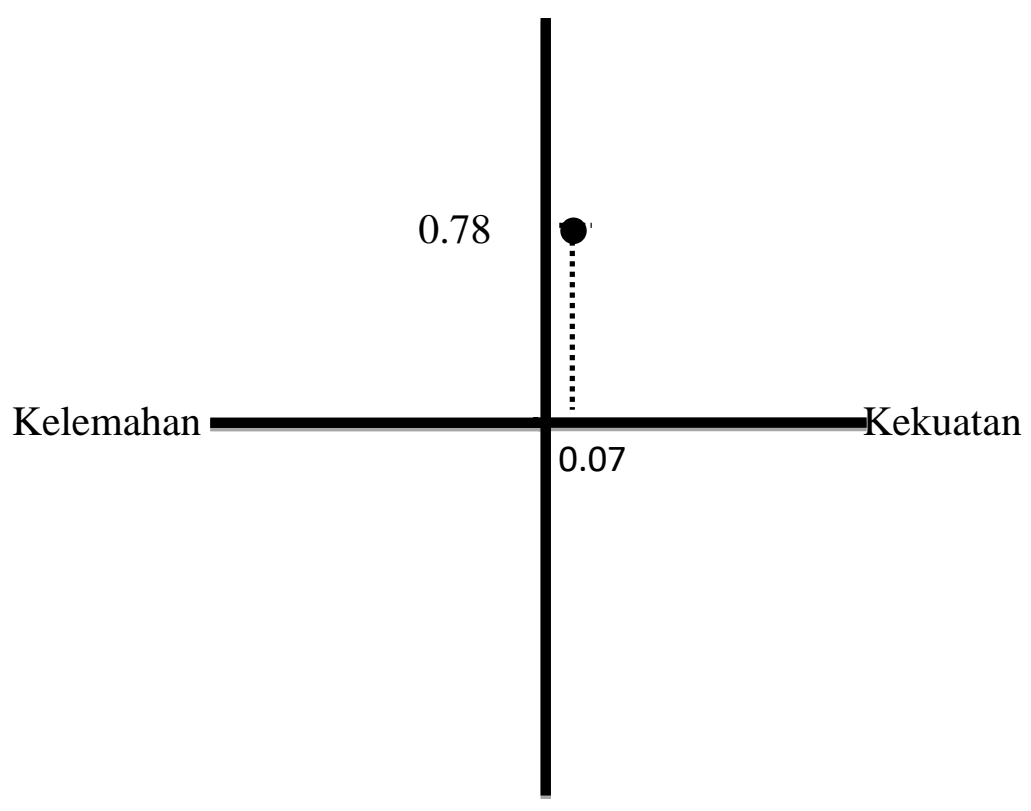

Ancaman

Gambar 2. Diagram SWOT LAZISNU 
Dari Gambar 2 dapat diambil kesimpulan bahwa posisi analisis SWOT di LAZISNU adalah pada kuadran pertama. Di mana kuadran pertama ini merupakan posisi yang sangat menguntungkan bagi LAZISNU. Karena pada posisi ini LAZISNU memiliki kekuatan dari internal LAZISNU dan memiliki banyak peluang dari eksternal LAZISNU. Dari kekuatan yang ada dapat dimanfaatkan untuk meraih peluang yang ada di eksternal LAZISNU. Selain itu apabila LAZISNU dapat memanfaatkan kekuatan dan peluang yang ada, secara tidak langsung akan mengurangi kelemahan yang dimiliki oleh LAZISNU.

Dengan posisi kuadran I ini strategi yang digunakan LAZISNU adalah strategi agresif dengan memaksimalkan kekuatan sehingga dapat merebut peluang tersebut. LAZISNU harus dapat memaksimalkan jaringan yang luas dan dukungan UPZIS disetiap kecamatan untuk edukasi tetang zakat kepada masyarakat di daerah masingmasing. Karena banyak masyarakat Magetan yang sudah wajib mengeluarkan zakat akan tetapi belum mengetahui bahwa harus mengeluarkan zakat maalnya. Sejauh ini, masyarakat hanya mengetahui bahwa zakat yang dikeluarkan itu sebatas zakat fitrah pada saat bulan puasa saja. Selain itu, LAZISNU juga harus lebih giat dalam sosialisasi dan edukasi terhadap masyarakat bahwa LAZISNU adalah lembaga zakat yang independen dan sudah mendapatkan payung hukum dalam pengelolaannya.

Selanjutnya, untuk meraih peluang yang ada adalah LAZISNU harus dapat mengidentifikasi muzakki baru dengan tetap membangun hubungan yang baik dengan muzakki yang lama. Dengan cara memanfaatkan dukungan ulama yang didapatkan dan perkembangan teknologi yang semakin maju guna memanfaatkan potensi zakat yang ada di Kabupaten Magetan.

\section{KESIMPULAN}

Dari diagram disimpulkan bahwa LAZISNU berada pada kuadran pertama. Di mana kuadran pertama ini merupakan posisi yang sangat menguntungkan bagi LAZISNU. Karena pada posisi ini LAZISNU memiliki kekuatan dari internal LAZISNU dan memiliki banyak peluang dari eksternal LAZISNU. Strategi yang digunakan LAZISNU adalah strategi agresif dengan memaksimalkan kekuatan sehingga dapat merebut peluang.

Dengan posisi kuadran I ini strategi yang digunakan LAZISNU adalah strategi agresif dengan memaksimalkan kekuatan sehingga dapat merebut peluang tersebut. 
LAZISNU harus dapat memaksimalkan jaringan yang luas dan dukungan UPZIS disetiap kecamatan untuk edukasi tetang zakat kepada masyarakat di daerah masingmasing. Karena banyak masyarakat Magetan yang sudah wajib mengeluarkan zakat akan tetapi belum mengetahui bahwa harus mengeluarkan zakat maalnya. Sejauh ini, masyarakat hanya mengetahui bahwa zakat yang dikeluarkan itu sebatas zakat fitrah pada saat bulan puasa saja. Selain itu, LAZISNU juga harus lebih giat dalam sosialisasi dan edukasi terhadap masyarakat bahwa LAZISNU adalah lembaga zakat yang independen dan sudah mendapatkan payung hukum dalam pengelolaannya.

\section{REFERENSI}

Anwar, A. (2020). Manajemen Zakat Infaq Dan Sedekah Dalam Upaya Peningkatan Status Mustahik Menjadi Muzakki Di Lembaga Amil Zakat Dompet Amal Insani (Lazdai) Lampung. UIN Raden Intan Lampung.

Departemen Agama RI. (2007). Al-Qur'an dan Terjemahannya Al-Jumanatul'ali.

Nurhayati, S., Siswantoro, D., Rahman, T., Menne, F., SASONGKO, C., WIYONO, S., ... FADILAH, S. R. I. (2019). Akuntansi dan Manajemen Zakat. Jakarta Selatan: Salemba Empat.

Nurul, H. (2015). Zakat Perspektif Mikro-Makro (Pendekatan Riset). Jakarta: Prenadamedia Group.

Pangiuk, A. (2020). Pengelolaan Zakat Di Indonesia. NTB: Forum Pemuda Aswaja.

Rafi'i, R., Tarmizi, A., \& Badaruddin, B. (2020). Analisis Faktor-Faktor Penyebab Kurang Minat Masyarakat Membayar Zakat Di Lazisnu Kota JambI. UIN Sulthan Thaha Saifuddin Jambi.

Rangkuti, F. (1998). Analisis SWOT teknik membedah kasus bisnis. Jakarta: Gramedia Pustaka Utama.

Safa'ah, E. M. (2019). Pengaruh Kompetensi Sumber Daya Manusia (SDM) Terhadap Kinerja Karyawan (Studi Kasus di BMT Arsyada Kantor Cabang Gaya Baru VIII). IAIN Metro.

Sedarmayanti. (2014). Manajemen Strategi. Bandung: PT. Refika Aditama.

Sugiyono. (2006). Metode Penelitian Kuantitatif Kualitatif dan R\&D. Bandung: CV. Alfabeta.

UU RI No. 23 Tahun 2011 Tentang Pengelolaan Zakat.

Wardoyo, P. (2011). Enam Alat Analisis Manajemen. Semarang: Semarang University Press. 